\title{
Antibacterial Activity of Indonesian Sponge Associated Fungi Against Clinical Pathogenic Multidrug Resistant Bacteria
}

\author{
Mada Triandala Sibero ${ }^{1,2^{*}}$, Ocky Karna Radjasa ${ }^{2,3}$, Agus Sabdono ${ }^{2,3}$, Agus Trianto ${ }^{3,4}$, Desy Wulan Triningsih ${ }^{4}$, Inggrid Debora Hutagaol \\ 'Department of Coastal Resources Management, Faculty of Fisheries and Marine Science, Diponegoro University, Semarang 50275, Central Java, Indonesia. \\ ${ }^{2}$ Laboratory of Tropical Marine Biotechnology, Marine Science and Oceanography Laboratory Building Lv. 2, Faculty of Fisheries and Marine Science, \\ Diponegoro University, Semarang 50275, Central Java, Indonesia. \\ ${ }^{3}$ Department of Marine Science, Faculty of Fisheries and Marine Science, Diponegoro University, Semarang 50275, Central Java, Indonesia. \\ ${ }^{4}$ Laboratory of Marine Natural Product, Integrated Laboratory of Diponegoro University, Semarang 50275, Central Java, Indonesia.
}

\begin{tabular}{|c|c|}
\hline ARTICLE INFO & ABSTRACT \\
\hline Article history: & \multirow{5}{*}{$\begin{array}{l}\text { Exploration of new source of antibiotics to combat multidrug-resistant bacteria is urgently needed. Indonesia as } \\
\text { archipelago country has a wide variety of marine organisms with potential as source of new antibacterial compounds } \\
\text { against MDRO. Aims of the study were to isolate sponge-associated fungi from sponge Cinachyrella sp. collected } \\
\text { from Pandang Island, North Sumatera, Indonesia, to screen potential fungi against clinical pathogenic MDR bacteria, } \\
\text { to identify the potential fungi; and to determine the best cultivation time for antibacterial production. Nine sponge- } \\
\text { associated fungi were successfully isolated. Result of agar plug method showed fungus PDSP } 5.7 \text { was the most potential } \\
\text { candidate which inhibited ESBL Escherichia coli, Salmonella enterica ser. Typhi, MRSA, and Staphylococcus } \\
\text { haemolyticus strain MDR. This fungus had } 100 \% \text { similarity to Trichoderma reesei. In malt extract broth, T. reesei } \\
\text { PDSP } 5.7 \text { had stationary phase from day } 12 \text { to day } 18 \text {. In addition, the widest antibacterial was performed by extract } \\
\text { from day } 15 \text {. Furthermore, fungal extract showed best antibacterial activity against S. enterica ser. Typhi strain MDR } \\
\text { with inhibition value of } 14.72 \pm 0.07 \mathrm{~mm}^{2} \text {. }\end{array}$} \\
\hline Received on: 09/10/2017 & \\
\hline Accepted on: $13 / 12 / 2017$ & \\
\hline Available online: $27 / 02 / 2018$ & \\
\hline $\begin{array}{l}\text { Key words: } \\
\text { Antibacterial, associated } \\
\text { fungi, MDR, Trichoderma. }\end{array}$ & \\
\hline
\end{tabular}

\section{INTRODUCTION}

The massive number of multidrug-resistant organisms (MDRO) infections nowday is caused by the irrational use of antibiotic in several decades ago (Alanis, 2005; de Simone et al., 2016; Cansizoglu and Toprak, 2017). Several pathogenic bacteria such as extended-spectrum beta-lactamase (ESBL) E. coli, methicillin-resistant S. aureus (MRSA), Staphylococcus haemolyticus, and Salmonella enterica ser. Typhi have been isolated from patients and identified as infectious MDRO (Hosseinkhani et al., 2016; Goudarzi et al., 2017; Lugito and Cucunawangsih, 2017; Shakya et al., 2017). As MDRO, these bacteria are resistant to antibiotics so that the urgency of finding the new antibiotic candidate has become very important.

\footnotetext{
${ }^{*}$ Corresponding Author

Mada Triandala Sibero, Student Dormitory of Diponegoro University, St. Sudharto SH., Tembalang, Semarang 50269, Central Java, Indonesia.E-mail: madatriandala@ hotmail.com
}

Previous studies discovered new antibacterial compounds from marine organisms such as algae, coral and sponge (Liu et al., 2014; Abdel-Raouf et al., 2015; Nguyen et al., 2017). Among all marine organisms, sponge is the most studied as source of bioactive compounds (Mehbub et al., 2014; Kumar and Pal, 2016). Beesoo et al. (2017) reported extract from Neopetrosia exigua contained beta-sitosterol and cholesterol. This extract inhibited $S$. aureus and Bacillus cereus with MIC and MBC values of $0.039 \mathrm{mg} / \mathrm{mL}$ and $0.078 \mathrm{mg} / \mathrm{mL}$. Furthermore, Wright et al. (2017) isolated dragmacidin G from Spongosorites sp. with broad spectrum antibacterial activity against $S$. aureus and Mycobacterium tuberculosis. At the same year, Nguyen et al. (2017) successfully discovered langcoquinone $\mathrm{C}$ and smenospongorine from Spongia $s p$. which had significant antibacterial against B. subtilis and $S$. aureus with MICs ranging from 6.25 to $25 \mu \mathrm{M}$. Admittedly, exploration of new antibiotics candidate from sponges leads to environmental issue. So that, the utilization of their associated microorganisms is commonly applied. 
Marine sponge-associated fungi are also known as a potential source for discovery of new antibiotic candidate (Handayani and Artasasta, 2017; Sibero et al., 2017). In addition, several discoveries were successfully isolate new compounds from sponge-associated fungi with biological activities (Zin et al., 2016; Noinart et al., 2017). Furthermore, Liu et al. (2017) isolated 11 compounds from sponge-derived fungus Aspergillus sydowii J05B-7F-4. Among 11 compounds, there were 5 diphenylethers which had antibacterial activity against human pathogen $S$. aureus. Fungus Pestalotiopsis heterocornis which isolated from sponge Phakellia fusca was reported to produce isocumarins 1-3. These compounds had antibacterial activity against $S$. aureus and B. subtilis with MIC values ranging from 25 to $100 \mu \mathrm{g} / \mathrm{mL}$ (Lei et al. 2017). Unfortunatelly, there are a few researches which study antibacterial activity of sponge-associated fungi against multidrug-resistant bacteria. Aims of the study were to isolate sponge-associated fungi from sponge Cinachyrella sp. collected from Pandang Island, North Sumatera, to screen potential fungi against clinical pathogenic MDR bacteria, to identify the potential fungi, and to determine the best cultivation time for antibacterial production.

\section{MATERIAL AND METHODS}

\section{Sponge Cinachyrella sp.}

Sponge Cinachyrella sp. was collected from Pandang Island, North Sumatera, Indonesia from a depth of $2 \mathrm{~m}$ by snorkeling. After the collection, approximietly $5 \times 5 \mathrm{~cm}^{2}$ sample was cut and kept in sterile zip lock plastic for fungal isolation.

\section{Clinical pathogenic MDR bacteria}

The clinical pathogenic MDR bacteria used in this study were clinical collections from Dr. Kariadi General Hospital Medical Center, Semarang, Central Java, Indonesia. ESBL E. coli, MRSA, S. haemolyticus and S. enterica ser. Typhi were used as test bacteria. ESBL and S. enterica ser. Typhi were re-cultured on MacConkey M081B agar from HiMedia while MRSA and $S$. haemolyticus were re-cultured on Nutrient Agar CM0003 from Oxoid Ltd. at $37^{\circ} \mathrm{C}$ for $24 \mathrm{~h}$.

\section{Fungal isolation and purification}

This study applied surface sterilization methods from Kjer et al. (2010) and Sibero et al. (2017) for fungal isolation with several modifications. Firstly, sponge was cut into 3 pieces in size $2 \times 1 \mathrm{~cm}^{2}$ and washed using sterile marine water then was immersed in alcohol $70 \%$ for $60 \mathrm{~s}$. After that, sponge was washed using sterile marine water to clean the alcohol residue. Lastly, each piece was tapped on a Malt Extract Agar (MEA) M137 HiMedia as a control of quality of surface sterilization method before placed on other MEA and incubated for 7 days $\left(27^{\circ} \mathrm{C}\right)$. During fungal isolation, a petri dish with MEA was opened as an environmental control. The fungal growth was observed daily. Each mycelium which grew on sponge was isolated and transferred to a new medium for further step.

\section{Antibacterial activity screening of sponge-associated fungi}

Agar plug method was carried out for antibacterial activity screening. All fungal isolates were refreshed on MEA for 7 days at $27^{\circ} \mathrm{C}$ while MDR bacteria were re-cultured for 24 $\mathrm{h}$ at $37^{\circ} \mathrm{C}$ and diluted to be $0.5 \mathrm{McF}$ arland in physiological saline solution. After that, MDR dilution was inoculated on Mueller Hinton Agar (MHA) from Merck KGaA. Each fungus with its agar medium were cut in circle shape then placed on an inoculated MHA medium and incubated for $24 \mathrm{~h}$ at $37^{\circ} \mathrm{C}$. Antibacterial activity was indicated by the presence of clear zone around fungal colony (Rahaweman et al., 2016; Sibero et al., 2017). Fungal isolate which able inhibited all tested bacteria was used for the further step as potential fungus.

Table 1: Antibacterial activity of sponge-associated fungi.

\begin{tabular}{lcccc}
\hline \multirow{2}{*}{$\begin{array}{l}\text { Fungal } \\
\text { Isolate }\end{array}$} & ESBL E. coli & $\begin{array}{c}\text { S. enterica } \\
\text { ser. Typhi }\end{array}$ & MRSA & S. haemolyticus \\
\cline { 2 - 5 } & - & - & + & + \\
\hline PDSP 5.1 & - & - & - & - \\
PDSP 5.2 & - & - & - & - \\
PDSP 5.3 & - & - & - & - \\
PDSP 5.4 & + & - & - & - \\
PDSP 5.5 & - & - & - & - \\
PDSP 5.6 & - & + & + & + \\
PDSP 5.7 & + & - & - & + \\
PDSP 5.8 & + & - & - & + \\
PDSP 5.9 & + & & & \\
\hline
\end{tabular}

(+: presence of inhibition zone; -: absence of inhibition zone).

\section{Fungal identification}

Identification through macro-microscopic and molecular approaches was carried for this study. Fungus was grown on MEA for 7 days. Microscopic characterization was done using slide culture method (Qiu et al., 2005). Furthermore, mycelia were taken for DNA extraction using Chelex 100 method. For DNA amplification, PCR mix was consisted of $12.5 \mu \mathrm{L}$ of GoTaq Green Master mix from Promega Corporation, $1 \mu \mathrm{L}$ of ITS 1, $1 \mu \mathrm{L}$ of ITS $4,10 \mu \mathrm{L}$ of $\mathrm{ddH} 2 \mathrm{O}$ and $0.5 \mu \mathrm{L}$ of DNA template. In addition, primer ITS1 (5'-TCC GTA GGT GAA CCT GCG G-3') and ITS4 (5'-TCC TCC GCT TAT TGA TAT GC-3') from Macrogen were applied. Fungal DNA was amplified with these following conditions: cDNA preheat at $95^{\circ} \mathrm{C}$ for $3 \mathrm{~m}, 30$ cycles of denaturation at $95^{\circ} \mathrm{C}$ for $1 \mathrm{~min}$, annealing at $51.80^{\circ} \mathrm{C}$ for $1 \mathrm{~min}$ and extension at $72^{\circ} \mathrm{C}$ for $1 \mathrm{~min}$ while the post cycling extension was done at $72^{\circ} \mathrm{C}$ for $7 \mathrm{~min}$. PCR product was sequenced by $1^{\text {st }}$ BASE DNA Laboratories Sdn Bhd, Malaysia. Lastly, phylogenetic three of potential fungus was reconstructed using MEGA.7 software package (Sibero et al., 2017).

\section{Fungal cultivation in broth medium for antibacterial assay and growth curve}

Potential fungus was cultivated in $250 \mathrm{~mL}$ of Malt Extract Broth (MEB) from Difco ${ }^{\mathrm{TM}}$ for 21 days at $27^{\circ} \mathrm{C}$. Fungus was harvested every three days. Fungal mycelia were separated using filter paper (Advantec 7, Ø $125 \mathrm{~mm}$ ). Filter paper had been dried in oven at $50^{\circ} \mathrm{C}$ for $24 \mathrm{~h}$ and weighed before used as blank $\left(W_{\mathrm{o}}\right)$. After separation, filter papers contained mycelia were dried 
in oven $\left(50^{\circ} \mathrm{C}\right)$ for $24 \mathrm{~h}$ then weighed $\left(W_{\mathrm{t}}\right)$. Mycelial weights was obtained using following simple mathematical formula and used to construct fungal growth curve while the broth media was used for further step. $\mathrm{pH}$ of media in each harvesting day was measured using $\mathrm{pH}$ meter.

$$
W_{\mathrm{m}}=W_{\mathrm{t}}-W_{\mathrm{o}}
$$

\section{Extraction of fungal metabolite}

Ethyl acetate was used for extraction of fungal metabolite. The ratio of media to solvent was 1:2 (v/v). Solvent were separated from media using separatory funnel then the solvent were evaporated using rotary evaporator at $37^{\circ} \mathrm{C}$.

Table 2: Antibacterial activity of fungal extract from different harvesting time.

\begin{tabular}{|c|c|c|}
\hline Bacteria & Day & Inhibition Zone (mm) \\
\hline \multirow{7}{*}{ ESBL $E$. coli } & 3 & $0.00 \pm 0.00^{\mathrm{a}}$ \\
\hline & 6 & $3.25 \pm 0.07^{\mathrm{b}}$ \\
\hline & 9 & $4.20 \pm 0.28^{\mathrm{c}}$ \\
\hline & 12 & $5.45 \pm 0.49^{\mathrm{d}}$ \\
\hline & 15 & $9.09 \pm 0.14 \mathrm{~g}^{*}$ \\
\hline & 18 & $8.20 \pm 0.00^{\mathrm{f}}$ \\
\hline & 21 & $7.58 \pm 0.16^{\mathrm{e}}$ \\
\hline \multirow{7}{*}{ S. enterica ser. Typhi } & 3 & $0.00 \pm 0.00^{\mathrm{a}}$ \\
\hline & 6 & $2.40 \pm 0.09^{\mathrm{b}}$ \\
\hline & 9 & $3.37 \pm 0.72^{\mathrm{c}}$ \\
\hline & 12 & $10.76 \pm 0.04^{\mathrm{d}}$ \\
\hline & 15 & $14.78 \pm 0.07^{7^{*}}$ \\
\hline & 18 & $14.64 \pm 0.06^{\mathrm{f}}$ \\
\hline & 21 & $13.47 \pm 0.04^{\mathrm{e}}$ \\
\hline \multirow{7}{*}{ MRSA } & 3 & $0.00 \pm 0.00^{\mathrm{a}}$ \\
\hline & 6 & $3.05 \pm 0.28^{\mathrm{b}}$ \\
\hline & 9 & $4.56 \pm 0.14^{c}$ \\
\hline & 12 & $5.28 \pm 0.07^{\mathrm{d}}$ \\
\hline & 15 & $7.40 \pm 0.14^{\mathrm{f}^{*}}$ \\
\hline & 18 & $7.25 \pm 0.04^{\mathrm{f}}$ \\
\hline & 21 & $7.09 \pm 0.02^{\mathrm{e}}$ \\
\hline \multirow{7}{*}{ S. haemolyticus } & 3 & $0.00 \pm 0.00^{\mathrm{a}}$ \\
\hline & 6 & $2.20 \pm 0.01^{\mathrm{b}}$ \\
\hline & 9 & $3.38 \pm 0.01^{\mathrm{c}}$ \\
\hline & 12 & $3.89 \pm 0.14^{\mathrm{d}}$ \\
\hline & 15 & $6.81 \pm 0.11^{\mathrm{g}^{*}}$ \\
\hline & 18 & $6.48 \pm 0.07^{\mathrm{f}}$ \\
\hline & 21 & $6.24 \pm 0.02^{\mathrm{e}}$ \\
\hline
\end{tabular}

(Data are mean \pm SD. Values with different shared letters in each MDR denote significant difference at $P<0.05$. Values with * denote the highest antibacterial activity in each MDR bacteria).

\section{In vitro antibacterial assay of fungal extract}

Fungal extract was diluted to $50 \mu \mathrm{g} / \mathrm{mL}, 125 \mu \mathrm{g} / \mathrm{mL}, 250$ $\mu \mathrm{g} / \mathrm{mL}, 500 \mu \mathrm{g} / \mathrm{mL}$ and $1000 \mu \mathrm{g} / \mathrm{mL}$ then tested against ESBL $E$. coli, MRSA, S. haemolyticus and S. enterica ser. Typhi according to CLSI (2016). The bacteria were inoculated on MHA using sterile cotton bud then $10 \mu \mathrm{L}$ of each concentration was injected into the paper disc ( $66 \mathrm{~mm}$ Oxoid $^{\mathrm{TM}}$ ) and placed onto the MHA medium then incubated for $24 \mathrm{~h}$ at $32^{\circ} \mathrm{C}$. Amoxicillin + Clavulanic acid $\left(30 \mu \mathrm{g} /\right.$ disc, $\varnothing 6 \mathrm{~mm}$ Oxoid $\left.^{\mathrm{TM}}\right)$ was used as positive control. The presence of clear zone indicated the antibacterial activity. Determination of antibacterial activity was done with two replications.

\section{Data analysis}

Data were analyzed using factorial design in SPSS software package version 18.0 for Windows with confidence interval 95\% $(P<0.05)$.

Table 3: Antibacterial activity of fungal extract at 15 days of cultivation.

\begin{tabular}{|c|c|c|}
\hline Bacteria & Day & $\begin{array}{c}\text { Inhibition Zone } \\
(\mathrm{mm})\end{array}$ \\
\hline \multirow{6}{*}{ ESBL E. coli } & 50 & $4.13 \pm 0.06^{\mathrm{a}}$ \\
\hline & 125 & $5.30 \pm 0.28^{b}$ \\
\hline & 250 & $8.72 \pm 0.07^{\mathrm{c}}$ \\
\hline & 500 & $8.83 \pm 0.08^{c}$ \\
\hline & 1000 & $9.10 \pm 0.14^{\mathrm{c}}$ \\
\hline & Amoxicillin + Clavulanic acid & $12.50 \pm 0.14^{\mathrm{d}^{*}}$ \\
\hline \multirow{6}{*}{$\begin{array}{l}\text { S. enterica ser. } \\
\text { Typhi }\end{array}$} & 50 & $8.19 \pm 0.02^{\mathrm{a}}$ \\
\hline & 125 & $8.49 \pm 0.04^{\mathrm{a}}$ \\
\hline & 250 & $11.90 \pm 0.42^{\mathrm{b}}$ \\
\hline & 500 & $14.40 \pm 0.15^{\mathrm{c}}$ \\
\hline & 1000 & $14.72 \pm 0.07^{\mathrm{c}^{*}}$ \\
\hline & Amoxicillin + Clavulanic acid & $12.20 \pm 0.28^{\mathrm{b}}$ \\
\hline \multirow{6}{*}{ MRSA } & 50 & $5.03 \pm 0.02^{\mathrm{a}}$ \\
\hline & 125 & $7.59 \pm 0.14^{\mathrm{b}}$ \\
\hline & 250 & $7.75 \pm 0.21^{\mathrm{b}}$ \\
\hline & 500 & $8.40 \pm 0.14^{\mathrm{c}}$ \\
\hline & 1000 & $8.97 \pm 0.09^{\mathrm{d}^{*}}$ \\
\hline & Amoxicillin + Clavulanic acid & $8.86 \pm 0.04^{\mathrm{d}}$ \\
\hline \multirow{6}{*}{ S. haemolyticus } & 50 & $5.09 \pm 0.16^{\mathrm{a}}$ \\
\hline & 125 & $7.60 \pm 0.23^{b}$ \\
\hline & 250 & $8.10 \pm 0.14^{c}$ \\
\hline & 500 & $8.21 \pm 0.00^{\mathrm{c}}$ \\
\hline & 1000 & $9.04 \pm 0.20^{\mathrm{d}}$ \\
\hline & Amoxicillin + Clavulanic acid & $10.25 \pm 0.07^{\mathrm{e}^{*}}$ \\
\hline
\end{tabular}

(Data are mean $\pm \mathrm{SD}$. Values with different shared letters in each MDR denote significant difference at $P<0.05$. Values with $*$ denote the highest antibacterial activity in each MDR bacteria).

\section{RESULT AND DISCUSSION}

There were 9 sponge associated fungi isolated from Cinachyrella sp. Each fungus had been screened against four clinical pathogenic MDR. During its growth on agar medium, fungus PDSP 5.7 secreted extracellular metabolites into medium. In agar plug method, fungal MEA medium contained extracellular 
metabolite were plugged on agar medium inoculated with tested MDR bacteria. In incubation time, fungal extracellular metabolites diffused from plug to the agar medium to kill tested MDR bacteria. The appearance of inhibition zone around the agar plug indicated the antibacterial activity (Balouiri et al., 2016; Rahaweman et al., 2016; Sibero et al., 2017). This study used ESBL E. coli and $S$. enterica ser. Typhi as representatives of gram negative bacteria while MRSA and $S$. haemolyticus as representatives of gram positive bacteria. The result of the screening with agar plug method is presented by Table 1 .
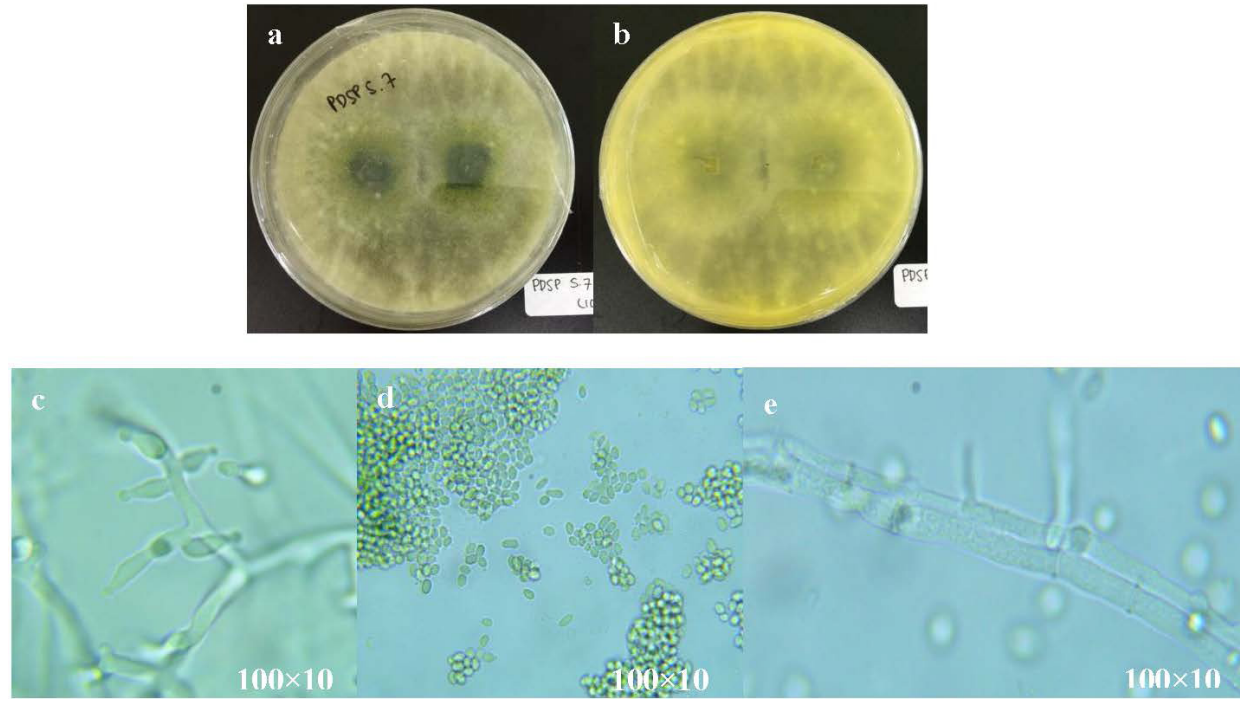

Fig. 1: Morphological characteristics of fungus PDSP 5.7. (a. top side, b. reverse side, c. conidiophore, d. conidia, e. hyphae).

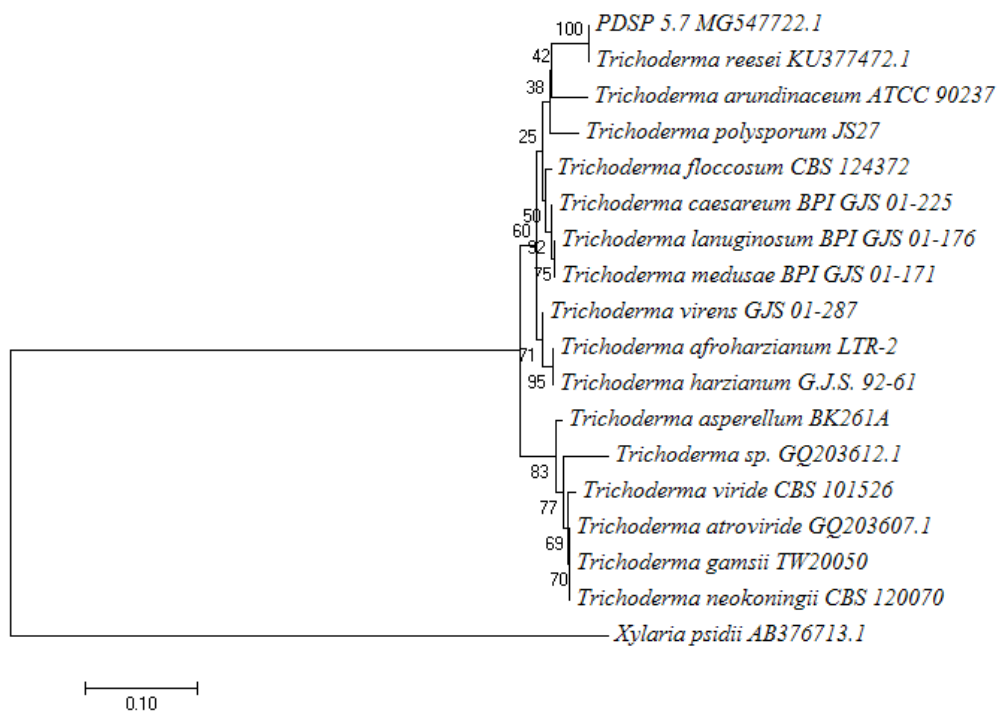

Fig. 2: Phylogram of genetic distance of fungus PDSP 5.7 using ITS rRNA region.

Table 1 shows 5 fungi which had antibacterial activity against clinical pathogenic MDR bacteria. Fungus PDSP 5.1 showed antibacterial activity against gram positive MDR, fungus PDSP 5.4 only showed antibacterial activity against ESBL E. coli, fungus PDSP 5.8 and PDSP 5.9 inhibited ESBL E. coli and S. haemolyticus. By contrast, fungus PDSP 5.7 had antibacterial activity against all tested MDR bacteria. Therefore, fungus PDSP 5.7 was selected as potential isolate and used further steps.
As a potential isolate, fungus PDSP 5.7 was identified with macro-microscopic and molecular approaches. Figure 1 (a-b) show fungal colony on MEA. It had white colony with green circular pattern on the middle of it. At room temperature $\left(27^{\circ} \mathrm{C}\right)$, this fungus produced yellow extracellular pigment which secreted into the agar medium. Figure 1 (c-e) show fugal microscopic morphology of fungus PDSP 5.7. This fungus had branching conidiophore with lageniform phialides, conidia ellipsodial nearly to oblong and septum in hyphae. These characteristics leaded 
fungus PDSP 5.7 to be judge as member of genus Trichoderma (Rahman et al., 2011; Qin and Zhuang 2016; Sibero et al. 2017). Molecular analysis was done for the further identification. The phylogenetic tree of fungus PDSP 5.7 is shown by Figure 2.

The phylogram shows the homology comparison of fungus PDSP 5.7 to several Trichoderma species. This fungus had $100 \%$ similarity to Trichoderma reesei KU377472.1. Fungi from genus Trichoderma are commonly isolated as spongeassociated fungi (Sibero et al., 2016; Mohamed-Benkada et al., 2016; Pang et al., 2017). T. reesei MPS 14.5/MT 04 was also found as fungal associate in Cinachyrella sp. from Panjang Island, Jepara, Indonesia with antibacterial activity (Sibero et al., 2017). Antibacterial activity from microorganisms is strongly related to its life phases (Tarman et al., 2013; Indarmawan et al. 2016; Ukhty et al., 2017). Fungus PDSP 5.7 has been registered in GeneBank as Trichoderma reesei with accession number MG547722.1. A growth curve is important to determine fungal life phase. Growth curve of T. reesei PDSP 5.7 is presented by Figure 3 .

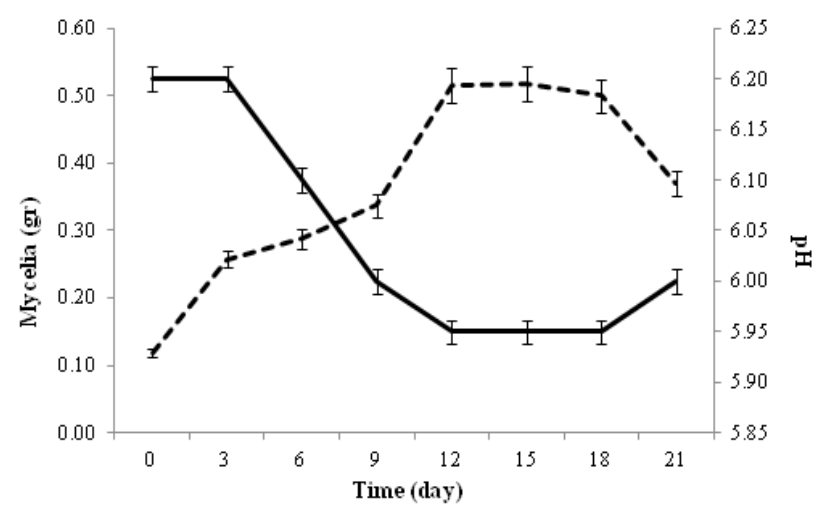

Fig. 3: Growth and pH curves of fungus PDSP 5.7 in MEB for 21 days of cultivation.

Fungus PDSP 5.7 passed log phase at day 3 to day 9 , while stationary phase started at day 12 to day 18 . The highest biomass of dry mycelia was produced at day $15(0.5180 \pm 0.001$ gr $)$ Usually, microorganisms produce secondary metabolites in stationary phase. Tarman et al. (2013) stated that endophytic fungi from Rhizophora mucronata produced the highest bioactive compounds on day 15 in PDB-based medium. Meanwhile, marine algicolous fungus Xylaria psidii KT30 produced the highest metabolite activity during stationary phase on day 21 in Hagem-based medium. Nutrient content in broth medium related to the fungal growth phase (Ukhty et al., 2017). Malt extract broth (MEB) used in this study as fermentation medium contain malt extract as carbon source and mycological peptone as nitrogen source. Sánchez et al. (2010) noted that carbon source has important role on antibiotic production. The $\mathrm{pH}$ of broth medium decreased during log phase then stable at stationary phase. It was caused by the fermentation done by the fungi (Indarmawan et al., 2016). Antibacterial activity of fungal extract in each harvesting time is shown by Table 2. For this step, fungal extracts were diluted to $1000 \mu \mathrm{g} / \mathrm{mL}$.

Diameter of inhibition zone from fungal extracts increased from day 3 to day 15 (Table 1). Day 15 had the highest inhibition zone against all clinical pathogenic MDR bacteria so that, we proposed 15 days as the optimum cultivation time for fungus T. reesei PDSP 5.7. As shown in Figure 2, day 15 was known as stationary phase of fungus $T$. reesei PDSP 5.7. We noted that, this fungus strongly inhibited Salmonella enterica ser. Typhi followed by ESBL $E$. coli, then $S$. haemolyticus and MRSA. The ability of fungus against gram negative and positive MDR bacteria indicated a broad spectrum antibacterial activity. Several studies reported that fungi demonstrated widest antibacterial activity in stationary phase (Tarman et al., 2013; Indarmawan et al., 2016; Ukhty et al., 2017). In stationary phase, fungi produce particular bioactive compounds to protect themselves from competitors (Manavathu and Vazquez, 2014). Furthermore, fungal extract from day 15 was dilluted to be $50 \mu \mathrm{g} / \mathrm{mL}, 125 \mu \mathrm{g} / \mathrm{mL}, 250 \mu \mathrm{g} /$ $\mathrm{mL}, 500 \mu \mathrm{g} / \mathrm{mL}$ and $1000 \mu \mathrm{g} / \mathrm{mL}$ then tested against ESBL E. coli, MRSA, S. haemolyticus and S. enterica ser. Typhi. The result of this assay is presented by Table 2 and Figure 4.

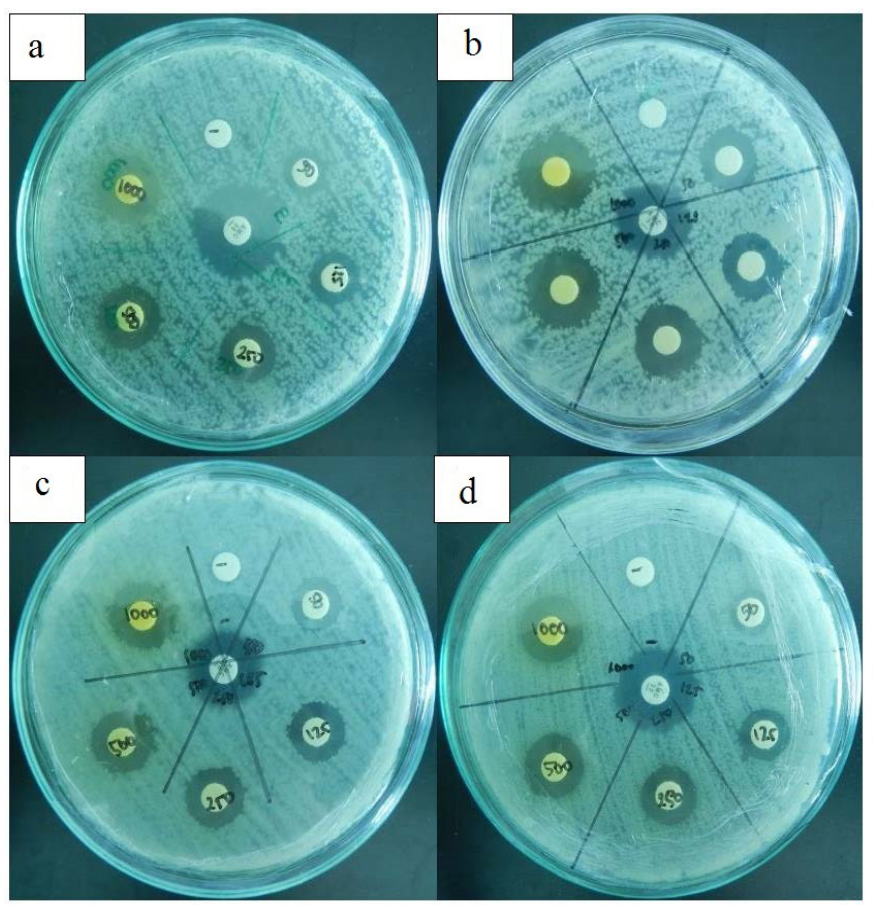

Fig. 4: Inhibition zone from fungal extract $T$. reesei PDSP 5.7 against (a) ESBL E. coli, (b) S. enterica ser. Typhi, (c) MRSA, (d) S. haemolyticus.

The range of inhibition zone value from fungal extract which harvested at day 15 was $4.13 \pm 0.06$ to $14.72 \pm 0.07$ (Table 2 ). The widest inhibition zone was performed by concentration $1000 \mu \mathrm{g} / \mathrm{mL}$ against $S$. enterica ser. Typhi, moreover this inhibition zone was wider than Amoxicillin + Clavulanic acid as positive control. In addition, this extract showed no significantly different $(P<0.05)$ against MRSA compared to positive control. The genus Trichoderma were known as potential source of polypeptide which has antibacterial activity. Panizel et al. (2013) stated that $T$. atrovorode isolated from sponge Axinella produced peptaibols with antibacterial activity against environmental bacteria such as Sporosarcina sp. (NB90); Bacillus sp. (NB36), Shewanella sp. (III.07) and Microbacterium sp. (PII.14). Fungus 
T. longibrachiatum MMS151 from blue mussels produced six long-chain peptaibols. Two of six long-chain peptaibols showed noticeable cytotoxic activity against $\mathrm{KB}$ cells, antibacterial activity against gram positive bacteria and antifungal activity against human pathogenic Aspergillus fumigatus (MohamedBenkada et al., 2016). Moreover, T. parareesei from Indonesian marine sponge produced yellow pigment which inhibited $E$. coli and S. enterica ser. Typhi strain MDR (Sibero et al., 2016). Beside polypeptides, Trichoderma members also produced polyketide compounds such as trichodermatides A-D, trichoderpyrone and trichoketides A and B with various biological activities (Sun et al., 2008; Yamazaki et al., 2015; Chen et al., 2017). For the further research, isolation of lead compounds from fungus $T$. reesei PDSP 5.7 is suggested to obtain the next generation of antibiotic.

\section{CONCLUSION}

There were nine sponge-associated fungi isolated from sponge Cinachyrella sp. Result of agar plug method showed fungus PDSP 5.7 was the most potential fungi which inhibited all tested MDR bacteria. Macro-microscopic and molecular identification judged this fungus as Trichoderma reesei MG547722.1. Fifteen day of cultivation was proposed as optimal time for cultivation of fungus T. reesei PDSP 5.7 MG547722.1. Fungal extract showed best antibacterial activity against $S$. enterica ser. Typhi, followed by ESBL E. coli, S. haemolyticus then MRSA.

\section{ACKNOWLEDGEMENT}

We thank to Directorate of Research and Community Development, Ministry of Research, Technology and Higher Education, Republic of Indonesia for the research grant through Program Magister Menuju Doktor Bagi Sarjana Unggulan (PMDSU) scheme, funding year 2017, No: 315-08/UN7.5.1/ $\mathrm{PP} / 2017$.

\section{CONFLICT OF INTEREST}

Authors declare that there is no conflict of interest.

\section{REFERENCES}

Abdel-Raouf N, Al-Enazi NM, Al-Homaidan AA, Ibraheem IBM, Al-Othman MR, Hatamleh AA. Antibacterial $\beta$-amyrin isolated from Laurencia microcladia. Arab J Chem, 2015; 8: 32-37.

Alanis AJ. Resistance to antibiotics: are we in the post-antibiotic era?. Arch Med Res, 2005; 36: 697-705.

Balouiri M, Sadiki M, Ibnsouda SK. Methods for in vitro evaluating antimicrobial activity: a review. J Pharm Anal, 2016; 6: 71-79.

Beesoo R, Bhagooli R, Neergheen-Bhujun VS, Li WW, Kagansky A, Bahorun T. 2017. Antibacterial and antibiotic potentiating activities of tropical marine sponge extracts. Comp Biochem Physiol C Toxicol Pharmacol, 2017; 196:81-90.

Cansizoglu MF, Toprak E. 2017. Fighting against evolution of antibiotic resistance by utilizing evovable antimicrobials drugs. Curr Genet, 2017; DOI: 10.1007/s00294-017-0703-x (Accessed 20 August 2017).

Chen L, Niu SB, Li L, Ding G, Yu M, Zhang GS, Wang MH, Li LY, Zhang T, Jia HM, Zhang HW, Shang Hai, Liu XZ, Zou ZM. Trichoderpyrone, a unique polyketide hybrid with a cyclopentenone-pyrone skeleton from the plant endophytic fungus Trichoderma gamsii. J Nat Prod, 2017; 80: 1944-1947.

de Simone B, Catena F, Sartelli M, di Saverio S, Coccolini F, Heyer A, Catena R, Ansaloni L. Common errors in the treatment of intraabdominal infections: the irrational use of antimicrobial agents. Emerg Care J, 2016; 12: 53-57.
Gopal M, Elumalai S, Arumugam S, Durairajpandian V, Kannan MA, Selvam E, Seetharaman S. GyrA ser83 and ParC trp 106 mutation in Salmonella enterica serovar Typhi isolated from typhoid fever patients in tetriary care hospital. J Clin Diagn Res, 2016; 10: DC14-8.

Gourdarzi M, Bahramian N, Satarzadeh Tabrizi M, Udo EE, Fiqueiredo AM, Fazeli M, Goudarzi H. Genetic diversity of methicillin resistant Staphylococcus aureus strains isolated from burn patients in Iran: ST239-SCCmec III/t037 emerges as the major clone. Microb Pathog, 2017; 105: 1-7.

Handayani D, Artasasta MA. Antibacterial and cytotoxic activities screening of symbiotic fungi extract isolated from marine sponge Neopetrosia chaliniformis AR-01. J App Pharm Sci, 2017; 7: 066-069.

Hosseinkhani F, Jabalameli F, Farahani NN, Taherikalani M, van Leeuwen WB, Emaneini M. Variable number of tandem repeat profiles and antimicrobial resistance patterns of Staphylococcus haemolyticus strains isolated from blood cultures in children. Infect Genet Evol, 2016; 38: 18-21.

Indarmawan, T., Mustopa, A. Z., Budiarto, B. R., Tarman, K. Antibacterial activity of extracellular protease isolated from an algicolous fungus Xylaria psidii KT30 against gram-positive bacteria. HAYATI J Biosci, 2016; 23: 73-78.

Kjer, J., Abdessamad, D., Amal, H. A., Peter, P. Methods for isolation of marine-derived endophytic fungi and their bioactive secondary products. Nat Protoc, 2010; 5:479-490.

Kumar MS, Pal AK. A review of bioactive compounds from marine organisms with special mention on the potential of marine sponges in pharmacological applications. J Mar Biol Ass India, 2016; 58: 87-96.

Lei H, Lin X, Han L, Ma J, Ma Q, Zhong J, Liu Y, Sun T, Wang J, Huang X. New metabolites and bioactive chlorinated benzophenone derivatives produced by a marine-derived fungus Pestalotiopsis heterocornis. Mar Drugs, 2016; 15: 69.

Liu Z, Cheng W, Liu D, van Ofwegen L, Proksch P, Lin W. Capnosane-type cembranoids from the soft coral Sarcophyton trocheliophorum with antibacterial effects. Tetrahedron, 2014; 70: 87038713.

Lugito NPH, Cucunawangsih. Antimicrobial resistance of Salmonella enterica serovar Typhi and Paratyphi isolates from a general hospital in Karawaci, Tangerang, Indonesia: a five-year review. Int J Microbiol, 2017; 2017: 1-7.

Manavathu EK, Vazquez JA. Antibacterial activities of stationary phase culture filtrates of Aspergillus fumigates. J Microbiol Exp, 2014; 1: 00020 .

Mehbub MF, Lei J, Franco C, Zhang W. Marine sponge derived natural products between 2001 and 2010: trends and opportunities for discovery of bioactives. Mar Drugs, 2014; 12: 4539-4577.

Mohamed-Benkada M, Pouchus YF, Verite P, Pagniez F, Caroff N, Ruiz N. Identification and biological activities of long-chain paptaibols produced by a marine-derived strain of Trichoderma longibrachiatum. Chemistry and Biochemistry, 2016; 13(5): 521-530.

Nguyen HM, Ito T, Kurimoto S, Ogawa M, Win NN, Hung VQ, Nguyen HT, Kubota T, Kobayashi J, Morita H. New merosesquiterpenes from a Vietnamese marine sponge of Spongia sp. and their biological activities. Bioorganic Med Chem Lett, 2017; 27: 3043-3047.

Noinart J, Buttachon S, Dethoup T, Gales L, Pereira JA, Urbatzka R, Freitas S, Lee M, Silva AMS, Pinto MMM, Vasconcelos V, Kijjoa A. A new ergosterol analog, a new Bis-Anthraquinone and anti-obesity activity of anthraquinones from the marine sponge-associated fungus Talaromyces stipitatus KUFA 0207. Mar Drugs, 2017; 15: 139.

Pang X, Lin X, Tian Y, Liang R, Wang J, Yang B, Zhou X, Kaliyaperumal K, Luo X, tu Z, Liu Y. Three new polyketides from the marine sponge-derived fungus Trichoderma sp. SCSIO41004. Nat Prod Res, 2017; 7:1-7.

Panizel I, Yarden O, Ilan M, Carmeli S. Eight new peptaibols from sponge-associated Trichoderma atroviride. Mar Drugs, 2013; 11: 4937-4960.

Qin WT, Zhuang WY. Seven wood-inhabiting new species of the genus Trichoderma (Fungi,Ascomycota) in viride clade. Sci Rep, 2016; 6:27074. 
Qiu WY, Yao YF, Zhu YF, Zhang YM, Zhou P, Jin YQ, and Zhang B. Fungal spectrum identified by a new slide culture and in vitro drug susceptibility using etest in fungal keratitis. Curr Eye Res, 2005; 30: $1113-1120$

Rahaweman AC, Pamungkas J, Madduppa H, Thoms C, Tarman K. Screening of endophytic fungi from chlorophyta and phaeophyta for antibacterial activity. IOP Conf Ser: Earth Environ Sci, 2016; 31: 012026.

Rahman A, Begum MF, Rahman M, Bari MA, Ilias GNM, Alam MF. Isolation and identification of Trichoderma species from different habitats and their use for bioconversion of solid waste. Turk J Biol, 2011; 35: 183-194.

Sánchez S, Chávez A, Forero A, Garcia-Huante Y, Romero A, Sánchez M, Rocha D, Sánchez B, Avalos M, Guzmán-Trampe S, Rodriguez-Sanoja R, Langley E, Ruiz B. Carbon source regulation of antibiotic production. J Antibiot, 2010; 63: 442-459.

Shakya P, Shrestha D, Maharjan E, Sharma VK, Paudyal R. ESBL production among $E$. coli and Klebsiella spp. causing urinary tract infection: a hospital based study. Open Microbiol J, 2017; 11: 23-30.

Sibero MT, Sabdaningsih A, Cristianawati O, Nuryadi H, Radjasa OK, Sabdono A, Trianto A.. Isolation, identification and screening antibacterial activity from marine sponge-associated fungi against multidrug-resistant (MDR) Escherichia coli. IOP Conf Ser: Earth Environ Sci, 2017; 55: 012028.

Sibero MT, Triningsih DW, Radjasa OK, Sabdono A, Trianto A. Evaluation of antimicrobial activity and identification of yellow pigmented marine sponge-associated fungi from Teluk Awur, Jepara, Central Java. I J Biotech, 2016; 21: 1-11.

Sun Y, Tian L, Huang J, Ma HY, Zheng Z, Lv AL, Yasukawa K, Pei YH. Trichodermatides A-D, novel polyketides from the marine-derived fungus Trichoderma reesei. Org Lett, 2008; 10: 393-396.

Tarman, K., Safitri, D., Setyaningsih, I. Endophytic fungi isolated from Rhizophora mucronata and their antibacterial activity. Squalen Bull. of Mar. \& Fish. Postharvest \& Biotech, 2013; 18: 69-76.

Ukhty N, Tarman K, Setyaningsih I. Isolation of endophytic fungi from the coastal plant Terong Pungo (Solanum sp.) and its antibacterial activity against oral pathogenic bacteria. Biotropia, 2017; 24: 9-15.

Wright AE, Killday KB, Chakrabarti D, Guzman EA, Harmody D, McCarthy PJ, Pitts T, Pomponi SA, Reed JK, Roberts BF, Felix CR, Rohde KH. Dragmacidin G, a bioactive bis-indole alkaloid from a deep water sponge of the genus Spongosorites. Mar Drugs, 2017; 15: 16.

Yamazaki H, Saito R, Takahashi O, Kirikoshi R, Toraiwa K, Iwasaki K, Izumikawa Y, Nakayama W, Namikoshi M. Trichoketides A and $\mathrm{B}$, two new protein tyrosine phosphatase $1 \mathrm{~B}$ inhibitors from the marinederived fungus Trichoderma sp. J. Antibiot, 2015; 68: 628-632.

Zin WWM, Buttachon S, Dethoup T, Fernandes C, Cravo S, Pinto MMM., Gale, L., Pereira JA, Silva AMSS, Sekeroglu N, Kijjoa, A. New cyclotetrapeptides and a new diketopiperzine derivative from the marine sponge-associated fungus Neosartorya glabra KUFA 0702. Mar Drugs, 2016; 14: 136.

How to cite this article:

Sibero MT, Radjasa OK, Sabdono A, Trianto A, Triningsih DW, Hutagaol ID. Anti-multidrug-resistant activity from fungi associated with sponge Cinachyrella sp. J App Pharm Sci, 2018; 8(02): 088-094. 